DOI: 10.14526/2070-4798-2020-15-2-47-54

\title{
About the practicability of wrestler's games use at the stage of initial training in Greco-Roman wrestling
}

\author{
Aleksandr S. Kuznetsov ${ }^{* 1}$, Boris A. Podlivaev ${ }^{2}$, Stanislav A. Kuznetsov ${ }^{3}$ \\ ${ }^{1}$ Chaykovskiy State Institute of Physical Culture \\ Chaykovskiy, Russia \\ ORCID: oooo-ooo3-4294-3755, kuznetsov-as@mail.ru* \\ ${ }^{2}$ Federal Center of Sports Reserve Training \\ Moscow, Russia \\ ORCID: o00o-0003-3292-5350, podlivaevb@mail.ru \\ ${ }^{3}$ Naberezhnye Chelny branch of Management University "TISBI" \\ Naberezhnye Chelny, Russia \\ ORCID: oooo-0002-7708-0403, stanislav.kuznetsov.79@mail.ru
}

\begin{abstract}
Competitive technical-tactical activity analysis in Greco-Roman wrestling proves the restricted character of technical arsenal [7]. Material. We had the hypothesis that attacking actions study at the initial stage of middle structures mastering, without games for holds inclusion would provide effective and active style of wrestling formation with less time and power expenditure for a hold. For the experiment realization we created 3 groups ( 26 people each), one control group and 2 experimental groups with different objectives, programs and conditions of pedagogical control according to the years of study. Research methods. Information sources analysis and summarizing, pedagogical observation, pedagogical experiment, competitive activity (throws) analysis among Greco-Roman style wrestlers, methods of mathematical statistics. Results. The research results prove insignificant differences between the average group indices and the absence of the distorting influence of physical qualities on the results of competitive activity of the respondents. At the same time, within the mentioned period there stayed only $57 \%$ of students in the control group, in the $1^{\text {st }}$ experimental group - $38 \%$, in the $2^{\text {nd }}$ experimental group - $59 \%$, which proves not only the effectiveness of the created methodology in educationaltraining aspect, but also in social-psychological aspect. Conclusion. As a results of three-year, natural pedagogical experiment, which included the stage of initial training and the first year of educational-training stage, we revealed that it is not reasonable to use in a wrestler's games tasks for combat for a hold at the stage of the initial training, as it leads to "inter-techniques" increase during the combat and it does harm to the attacking manner of the combat conduct.
\end{abstract}

Keywords: games of wrestlers, pedagogical experiment, stage of initial training, training process, preserving the contingent of those, who train.

For citation: Kuznetsov A.S.*, Podlivaev B.A., Stanislav A. Kuznetsov. About the practicability of wrestler's games use at the stage of initial training in Greco-Roman wrestling. Pedagogical-psychological and medical-biological problems of physical culture and sport. 2020; 15(2): 38-44. DOI: 10.14526/20704798-2020-15-2-47-54

According to the results of pedagogical observations, championships of Russia, we revealed that technical arsenal of wrestlers during the standing combat for $70 \%$ consists of knocking down and bowling over. In the referee's position mainly turn-overs and back body-lock throws of the opponent were used. The main time period of the combat includes manoeuvring, squeezes, overbalance, searching for the best position for the attacking actions realization. It proves serious drawbacks in methodology of a long-term training [2]. In terms of great amount of educationalmethodical material in Greco-Roman wrestling according to the kinds of training (technical, physical, functional and theoretical) there is no complete and system approach and it doesn't provide qualitative training process organization in training sports reserve and contingent preservation at the stages of a long-terms training $[1,3,5]$. First of all it is closely connected with the stage of initial training, when coaches are guided by the subjective experience and administration of sports schools (SS) and sports schools of the Olympic reserve (SSOR) can't organize effective control over the results of federal standard demands fulfillment. It leads to the restricted formation of technical-tactical arsenal, 
functional overloads, lack of staginess, which has a negative influence on the amount of training people, groups size decrease not only at the stage of initial training, but at other stages of specific educational component restricted character [4]. Special literature analysis, survey among the specialists, pedagogical observations prove considerable potential of the quality of sports reserve training increase in GrecoRoman wrestling owing to the content of kinds of training improvement $[3,5,9]$.

Together with the mentioned drawbacks in the methodological base of sports training among Greco-Roman style wrestlers there is one more serious disadvantage, which is presented in a form of a novation. According to the results of pedagogical observations during town and regional competitions, which were held by means of taking down technical actions shorthand and timing, we revealed lack of activity (the amount of attempts to realize real hold). It is obviously connected with wrestler's games introduction into the training process at the initial stage of training, which included struggle for a hold and hold avoidance (6).

Wrestler's games are successfully used in Greco-Roman wrestling at the training stage (sports Table 1 - Conditions of teaching during natural pedagogical experiment concerning the expediency of a wrestler's game study with the struggle for a hold at the stage of initial training

\begin{tabular}{|c|c|c|c|}
\hline $\begin{array}{l}\text { Year of } \\
\text { study }\end{array}$ & Control group & $\begin{array}{c}\text { The } 1^{\text {st }} \text { experimental } \\
\text { group }\end{array}$ & $\begin{array}{c}\text { The } 2^{\text {nd }} \text { experimental } \\
\text { group }\end{array}$ \\
\hline $\mathbf{1}$ & $\begin{array}{l}\text { Teaching with the games } \\
\text { inclusion for contact, for holds, } \\
\text { squeezes, pulling }\end{array}$ & Without games inclusion & $\begin{array}{l}\text { Teaching with the games } \\
\text { inclusion for squeezes, } \\
\text { pulling, but without the } \\
\text { games for contact and } \\
\text { holds }\end{array}$ \\
\hline 2 & The same & Without games inclusion & The same \\
\hline 3 & The same & Without games inclusion & $\begin{array}{l}\text { Teaching with the games } \\
\text { for contact, squeezes and } \\
\text { struggle for a hold }\end{array}$ \\
\hline \multicolumn{4}{|c|}{$\begin{array}{l}\text { Effectiveness evaluation criteria: } \\
\text { - activity index- the ratio of a minute amount of attempts to realize real holds to } 10 \text { attempts in a minute; } \\
\text { - quantitative index of effectiveness; } \\
\text { - qualitative index of effectiveness; } \\
\text { - profitableness - the ratio of the won points to the won and lost points; } \\
\text { - contingent preservation of those, who train in \% }\end{array}$} \\
\hline
\end{tabular}


At the same time, having passed the "admission" test, the respondents corresponded with physical normatives for sports schools (SS) admission, according to the average group indices they didn't differ much.

In the groups the amount of respondents increased normative demands in groups content of the initial training stage, it was connected with the necessity to have sufficient amount of respondents at the end of the $3^{\text {rd }}$ year of studying and with the degree of contingent preservation.

The respondents from the control group trained using wrestler's games during each lesson, including struggle for a hold, in accordance with weekly schemes of lessons (table 2).

Table 2 - Scheme of the lessons in weekly cycles in the control group (C) for the effectiveness of a wrestler's games use at the stage of the initial training in Greco-Roman wrestling

\begin{tabular}{|c|c|c|c|c|c|c|c|c|c|c|c|}
\hline № & $\begin{array}{l}\text { Part of } \\
\text { the lesson }\end{array}$ & Content of the lesson & & $\begin{array}{l}\text { le } \\
\text { ar } \\
\text { ud }\end{array}$ & & & $\begin{array}{l}\text { he } 2 \\
\text { ear } \\
\text { tud }\end{array}$ & & & $\begin{array}{l}\text { e } \\
\text { ar } \\
\text { ud }\end{array}$ & \\
\hline 1. & \multirow{7}{*}{$\begin{array}{l}\text { Preparatory } \\
\text { part }\end{array}$} & Introductory & 1 & 3 & 5 & 1 & 3 & 5 & 1 & 3 & 5 \\
\hline 2. & & General preparatory & + & + & + & + & + & + & + & + & + \\
\hline 3. & & Playing exercises & + & + & + & + & + & + & + & + & + \\
\hline $4 \cdot$ & & $\begin{array}{c}\text { Games of a wrestler without a } \\
\text { struggle for a hold }\end{array}$ & + & + & + & + & + & + & + & + & + \\
\hline 5 & & $\begin{array}{c}\text { Games of a wrestler with a struggle } \\
\text { for a hold }\end{array}$ & + & + & + & + & + & + & + & + & + \\
\hline 6. & & Self-insurance & + & + & + & + & + & + & + & + & + \\
\hline 7. & & Introductory exercises & + & + & + & + & + & + & + & + & + \\
\hline 8. & \multirow{20}{*}{$\begin{array}{l}\text { The main } \\
\text { part }\end{array}$} & Earlier studied material review & + & + & + & + & + & + & + & + & + \\
\hline 9. & & Techniques study & + & + & + & + & + & + & + & + & + \\
\hline 10. & & Techniques study with preparations & & + & + & + & + & + & + & + & + \\
\hline 11. & & Defense study against the techniques & + & + & + & + & + & + & + & + & + \\
\hline 12. & & Counter-holds study & & + & + & + & + & + & + & + & + \\
\hline 13. & & Techniques combinations study & & + & + & + & + & + & + & + & + \\
\hline 14. & & Techniques mastering & & + & + & & + & + & + & + & + \\
\hline 15. & & Defense and counter-holds mastering & & + & + & + & + & + & + & + & + \\
\hline 16. & & Techniques combinations mastering & & & + & + & + & + & + & + & + \\
\hline 17. & & Referee`s position techniques study & + & + & + & + & + & + & + & + & + \\
\hline 18. & & Techniques study with preparations & + & + & + & + & + & + & + & + & + \\
\hline 19. & & Defense study & & + & + & & + & + & + & + & + \\
\hline 20. & & Counter-holds study & & + & + & & + & + & + & + & + \\
\hline 21. & & Techniques combinations study & & & + & & + & + & + & + & + \\
\hline 22. & & Techniques mastering & & + & + & & + & + & + & + & + \\
\hline 23. & & Defense and counter-holds mastering & & + & + & & + & + & + & + & + \\
\hline 24. & & Techniques combinations mastering & & & + & & & + & + & + & + \\
\hline 25. & & Training combats & & + & & & + & & & + & \\
\hline 26. & & Educational-training combats & & & + & & & + & & & + \\
\hline 27. & & Training combats & & & + & & & + & & & + \\
\hline 28. & \multirow{2}{*}{$\begin{array}{l}\text { The final } \\
\text { part }\end{array}$} & Group power-oriented exercises & + & + & + & + & + & + & + & + & + \\
\hline 29. & & Relaxation exercises & + & + & + & + & + & + & + & + & + \\
\hline
\end{tabular}


The respondents of the $1^{\text {st }}$ experimental group during three years of studying didn't use wrestler's games in accordance with weekly schemes of lessons (table 3).

Table 3 -Schemes of lessons in weekly cycles of lessons of the $1^{\text {st }}$ experimental group (E-1) for the effectiveness of a wrestler's games use at the stage of the initial training in Greco-Roman wrestling

\begin{tabular}{|c|c|c|c|c|c|c|c|c|c|c|c|}
\hline No & $\begin{array}{l}\text { Part of } \\
\text { the lesson }\end{array}$ & Content of the lesson & \multicolumn{3}{|c|}{$\begin{array}{l}\text { The } 1^{\text {st }} \\
\text { year of } \\
\text { study }\end{array}$} & \multicolumn{3}{|c|}{$\begin{array}{l}\text { The } 2^{\text {nd }} \\
\text { year of } \\
\text { study }\end{array}$} & \multicolumn{3}{|c|}{$\begin{array}{c}\text { The } 3^{\text {rd }} \\
\text { year of } \\
\text { study }\end{array}$} \\
\hline 1. & \multirow{7}{*}{$\begin{array}{l}\text { Preparatory } \\
\text { part }\end{array}$} & Introductory & 1 & 3 & 5 & 1 & 3 & 5 & 1 & 3 & 5 \\
\hline 2. & & General preparatory & + & + & + & + & + & + & + & + & + \\
\hline 3. & & Playing exercises & + & + & + & + & + & + & + & + & + \\
\hline 4. & & $\begin{array}{l}\text { Games of a wrestler without a } \\
\text { struggle for a hold }\end{array}$ & & & & & & & & & \\
\hline 5. & & $\begin{array}{l}\text { Games of a wrestler with a struggle } \\
\text { for a hold }\end{array}$ & & & & & & & & & \\
\hline 6. & & Self-insurance & + & + & + & + & + & + & + & + & + \\
\hline 7. & & Introductory exercises & + & + & + & + & + & + & + & + & + \\
\hline 8. & \multirow{20}{*}{$\begin{array}{l}\text { The main } \\
\text { part }\end{array}$} & Earlier studied material review & + & + & + & + & + & + & + & + & + \\
\hline 9. & & Techniques study at a stand & + & + & + & + & + & + & + & + & + \\
\hline 10. & & Techniques study with preparations & & + & + & + & + & + & + & + & + \\
\hline 11. & & Defense study against the techniques & & + & + & + & + & + & + & + & + \\
\hline 12. & & Counter-holds study & & + & + & + & + & + & + & + & + \\
\hline 13. & & Techniques combinations study & & & + & + & + & + & + & + & + \\
\hline 14. & & Techniques mastering & & + & + & & + & + & + & + & + \\
\hline 15. & & Defense and counter-holds mastering & & + & + & + & + & + & + & + & + \\
\hline 16. & & Techniques combinations study & & & + & + & + & + & + & + & + \\
\hline 17. & & Referee`s position techniques study & + & + & + & + & + & + & + & + & + \\
\hline 18. & & Techniques study with preparations & & + & + & + & + & + & + & + & + \\
\hline 19. & & Defense study & & + & + & & + & + & + & + & + \\
\hline 20. & & Counter-holds study & & + & + & & + & + & + & + & + \\
\hline 21. & & Techniques combinations study & & + & + & + & + & + & + & + & + \\
\hline 22. & & Techniques mastering & & + & + & & + & + & + & + & + \\
\hline 23. & & Defense and counter-holds mastering & & + & + & & + & + & + & + & + \\
\hline 24. & & Techniques combinations mastering & & + & + & & + & + & + & + & + \\
\hline 25. & & Training combats & & + & & & + & & & + & \\
\hline 26. & & Educational-training combats & & & + & & & + & & & + \\
\hline 27. & & Training combats & & & + & & & + & & & + \\
\hline 28. & \multirow{2}{*}{$\begin{array}{l}\text { The final } \\
\text { part }\end{array}$} & Group power-oriented exercises & + & + & + & + & + & + & + & + & + \\
\hline 29. & & Relaxation exercises & + & + & + & + & + & + & + & + & + \\
\hline
\end{tabular}


The respondents of the $2^{\text {nd }}$ experimental group during the $1^{\text {st }}$ and the $2^{\text {nd }}$ years of study studied the same attacking techniques, in case of standing combat, without using elements of struggle for holds in a wrestler's game in accordance with weekly schemes of lessons (table 4).

Table 4 - Schemes of lessons in weekly cycles of the $2^{\text {nd }}$ experimental group (E-2) for the effectiveness of a wrestler's games use at the stage of the initial training in Greco-Roman wrestling

\begin{tabular}{|c|c|c|c|c|c|c|c|c|c|c|c|}
\hline № & $\begin{array}{l}\text { Part of } \\
\text { the lesson }\end{array}$ & Content of the lesson & \multicolumn{3}{|c|}{$\begin{array}{l}\text { The } 1^{\text {st }} \\
\text { year of } \\
\text { study }\end{array}$} & \multicolumn{3}{|c|}{$\begin{array}{l}\text { The } 2^{\text {nd }} \\
\text { year of } \\
\text { study }\end{array}$} & \multicolumn{3}{|c|}{$\begin{array}{l}\text { The } 3^{\text {rd }} \\
\text { year of } \\
\text { study }\end{array}$} \\
\hline 1. & \multirow{7}{*}{$\begin{array}{l}\text { Preparatory } \\
\text { part }\end{array}$} & Introductory & 1 & 3 & 5 & 1 & 3 & 5 & 1 & 3 & 5 \\
\hline 2. & & General preparatory & + & + & + & + & + & + & + & + & + \\
\hline 3. & & Playing exercises & + & + & + & + & + & + & + & + & + \\
\hline 4. & & $\begin{array}{l}\text { Games of a wrestler without a } \\
\text { struggle for a hold }\end{array}$ & + & + & + & + & + & + & + & + & + \\
\hline 5 . & & $\begin{array}{l}\text { Games of a wrestler with a } \\
\text { struggle for a hold }\end{array}$ & & & & & & & + & + & + \\
\hline 6. & & Self-insurance & + & + & + & + & + & + & + & + & + \\
\hline 7. & & Introductory exercises & + & + & + & + & + & + & + & + & + \\
\hline 8. & \multirow{20}{*}{$\begin{array}{l}\text { The main } \\
\text { part }\end{array}$} & Earlier studied material review & + & + & + & + & + & + & + & + & + \\
\hline 9 . & & Techniques study at a stand & + & + & + & + & + & + & + & + & + \\
\hline 10. & & Techniques study with preparations & & + & + & + & + & + & + & + & + \\
\hline 11. & & Defense study against the techniques & & + & + & + & + & + & + & + & + \\
\hline 12. & & Counter-holds study & & + & + & + & + & + & + & + & + \\
\hline 13. & & Techniques combinations study & & & + & + & + & + & + & + & + \\
\hline 14. & & Techniques mastering & & + & + & & + & + & + & + & + \\
\hline 15 . & & Defense and counter-holds mastering & & + & + & & + & + & + & + & + \\
\hline 16. & & Techniques combinations mastering & & + & + & & + & + & + & + & + \\
\hline 17. & & Referee`s position techniques study & + & + & + & + & + & + & + & + & + \\
\hline 18. & & Techniques study with preparations & & + & + & & + & + & + & + & + \\
\hline 19. & & Defense study & & + & + & & + & + & + & + & + \\
\hline 20. & & Counter-holds study & & + & + & & + & + & + & + & + \\
\hline 21. & & Techniques combinations study & & + & + & & + & + & + & + & + \\
\hline 22. & & Techniques mastering & & + & + & & + & + & + & + & + \\
\hline 23. & & Defense and counter-holds mastering & & + & + & & + & + & + & + & + \\
\hline 24. & & Techniques combinations mastering & & & + & & + & + & + & + & + \\
\hline 25. & & Training combats & & + & & & + & & & + & \\
\hline 26. & & Educational-training combats & & & + & & & + & & & + \\
\hline 27. & & Training combats & & & + & & & + & & & + \\
\hline 28. & \multirow{2}{*}{$\begin{array}{l}\text { The final } \\
\text { part }\end{array}$} & Group power-oriented exercises & + & + & + & + & + & + & + & + & + \\
\hline 29. & & Relaxation exercises & + & + & + & + & + & + & + & + & + \\
\hline
\end{tabular}


During the $3^{\text {rd }}$ year of study the second experimental group used the wrestler's game including the struggle for holds, in accordance with weekly schemes of lessons (table 4).

In all three groups the program of referee`s position combat study and combat in a lying position stayed unchanged.

Moreover, during the $1^{\text {st }}$ and the $2^{\text {nd }}$ years of study the defense, counter-holds, dynamic preparations for throws and throws combinations were excluded.

Competitions were not held at the end of the $1^{\text {st }}$ year of study, in accordance with the programs for SS.

At the end of the $3^{\text {rd }}$ year of study all respondents went through competitions in terms of other sports schools representatives participation.

Each respondent of the experiment had 6 combats, he had to face 2 representatives of each experimental group and shouldn't fight with the representative of own group. In general 192 combats were held.

\section{RESULTS AND DISCUSSION}

As a result the respondents from the control group had activity index (AI) increase till 0,22 , their quantitative index of effectiveness (QNIE) decreased till 0,27 and qualitative index of effectiveness (QLIE) increased till o,16. Profitableness index (Pi) decreased till 0,52 .

Among the participants of the $1^{\text {st }}$ experimental group the indices increased: AI - 0,28, QNIE - 0,33, QLIE - 0,17. However, Pi decreased $(0,47)$.

Among the respondents of the $2^{\text {nd }}$ experimental group AI was 0,34, QNIE - 0,42 and QLIE - 0,21. Pi was 0,62, which proves higher level of confidence in effectiveness of attack, in terms of high valid interval of intergroup difference $(\mathrm{p}<$ o,01).

In comparison according to the years of studying, the representatives of the control group had significant AI increase, according to QNIE their results considerably decreased, according to QLIE their results increased insignificantly and Pi index sharply decreased.

The respondents from E-1 group had insignificant AI increase, according to QNIE the results increased significantly. According to QLIE the results increased significantly and according to Pi the results decreased.

The representatives of E-2 had AI, QNIE, QLIE and Pi results considerable increase.

At the end of 3-year experiment we organized "exit" testing of physical qualities the results of which prove insignificant difference between the average group indices and the absence of the distorting influence of physical qualities on the results of the respondents competitive activity. At the same time, within the mentioned period there stayed only $57 \%$ of students in the control group, in the 1 st experimental group - $38 \%$, in the 2nd experimental group - $59 \%$, which proves not only the effectiveness of the created methodology in educational-training aspect, but also in social-psychological aspect.

\section{CONCLUSION}

1. The advantage of competitive results of control group representatives after the $2^{\text {nd }}$ year of study over the respondents from the $1^{\text {st }}$ and the $2^{\text {nd }}$ experimental groups was achieved owing to early formation of their competitive actions complex, especially struggle for the hold and the hold use as a static defense.

2. Competitive indices decrease among the participants of the control group after the third year of studying proves negative influence of early struggle for a hold mastering, as owing to static defense provision there is no stimulus to master dynamic defense and high level of static security causes lack of confidence in the success of the attacking action, especially during standing combat and stimulates to use expectative tactics.

3. The advantage of competitive results of the respondents from the $2^{\text {nd }}$ experimental group over the results of the representatives from the $1^{\text {st }}$ experimental group and that the absence of the struggle for a hold in playing tasks helped to form an active style of wrestling at the initial stage of training.

4. Complete absence of a wrestler's games in the $1^{\text {st }}$ experimental group led to considerable elimination of students, starting from the $1^{\text {st }}$ year of studying.

As results of three-year, natural pedagogical experiment, which included the stage of initial 
training and the first year of educational-training stage, we revealed that it is not reasonable to use in a wrestler's games tasks for combat for a hold at the stage of the initial training, as it leads to "intertechniques" increase during the combat and it does harm to the attacking manner of the combat conduct

\section{REFERENCES}

1. Boltikov Yu.V. Motivational factors increase in order to provide mass character and effectiveness of educational-training work in wrestling section. Candidate's thesis. Moscow: Moscow State Academy of Physical Culture. 2002: 23.

2. Kuznetsov A.S., Mubarakzyanov R.B. The influence of competitive activity rules change among the athletes, who go in for Greco-Roman wrestling. Pedagogiko-psihologicheskie I medicobiologicheskie problemy fizicheskoj kul'tury I sporta = Pedagogico-psychological and medicobiological problems of physical culture and sport. 2014; 1(30): 55-61. DOI: 10.14526/18_2014_18 [In Russ., In Engl.]

3. Kuznetsov A.S. Organizationalmethodical basis of a long-term technical-tactical training in Greco-Roman wrestling. Doctor's thesis. Krasnodar. KSAPC. 2002: 471.

4. Kuznetsov A.S. Organizationalmethodical basis of the contingent of students preservation at sports school for children teen-agers. Fizicheskaya kul'tura: vospitanie, obrazovanie, trenirovka. 2002; 1: 30-32 [In Russ.].
5. Kuznetsov A.S. The basic technical training optimization among Greco-Roman style wrestlers. Doctor's thesis. Krasnodar. KSAPC. 1995: 215 .

6. Kuznetsov A.S., Novakovskiy S.V., Solomakhin O.B. About the expediency of parallel attack and defense study in Greco-Roman wrestling at the stage of initial training. Pedagogikopsihologicheskie I medico-biologicheskie problemy fizicheskoj kul'tury I sporta = The Russian journal of Physical Education and Sport. 2018; 13(1): 1626. DOI: 10/14526/01_2018_279

7. Podlivaev B.A. Competitive activity analysis among wrestlers during the Olympic tournament in Sydney in Greco-Roman and freestyle wrestling. Sportivnye edinoborstva na rubezhe stoletij: puti I perspektivy razvitiya. Vserossijskaya nauchnio-prakticheskaya konferenciya, posbyachennaya 8o-letiyu professor kafedry E.M. Chumakova [Sports single combats at the edge of centuries: ways and prospects of development. AllRussian scientific-practical conference, dedicated to the $80^{\text {th }}$-anniversary of wrestling department professor E.M. Chumakov]. Moscow: SRAPC. 2001: 14-19 [In Russ.].

8. Podlivaev B.A. Training tasks modeling in sports wrestling. Teoriya I praktika fizicheskoj kul'tury $=$ Theory and practice of physical culture. 1999; 9: 55-57.

9. Solomakhin O.B. Pedagogical principles ranking in methodology of the initial stage of training in sports wrestling. Candidate's thesis. Moscow. 2002: 38.

\section{Submitted: 20.05.2020}

\section{Author's information:}

Aleksandr S. Kuznetsov - Doctor of Pedagogics, Professor, Chaykovskiy State Institute of Physical Culture, 617764, Russia, Chaykovskiy, Lenina str., House 67, e-mail: kuznetsov-as@mail.ru

Boris A. Podlivaev - Candidate of Pedagogics, Professor, Federal Center of Sports Reserve Training, 105064, Russia, Moscow, Kazakova str., House 18/8, e-mail: podlivaevb@mail.ru

Stanislav A. Kuznetsov - Candidate of Pedagogics, Associate Professor, Naberezhnye Chelny branch of Management University "TISBI", 423806, Russia, Naberezhnye Chelny, Komsomol'skaya nab., House 6, e-mail: stanislav.kuznetsov.79@mail.ru 